\title{
MODELLING OF PREVOCATIONAL EDUCATION OF STUDENTS WITH SPECIAL EDUCATIONAL NEEDS: SITUATION AND OPPORTUNITIES
}

\author{
Ingrida Baranauskienė \\ Aistè Valaikienè \\ Šiauliai University
}

\begin{abstract}
The aim of the present article - to reveal the directions of prevocational education of students with SEN, actual situation and opportunities. In 2012 in Lithuania the research of the Delphi group was performed where 13 experts having direct pedagogical experience in working with students having SEN participated. In the article the influence of traditions in the country on the success of prevocational education, the importance of the creation of the interaction child-family-school-community have been analyzed, the main aims of prevocational education, actual situation and directions to be improved have been revealed.
\end{abstract}

Keywords: career planning, prevocational education, students with SEN.

\section{Introduction}

As Jurevičiūte (2007) points out the beginnings of the researches in prevocational education in Lithuania reaches the 19the century and the beginning of the $20^{\text {th }}$ century, however, deeper interest in the issues of choosing a profession started and theoretical basis for vocational orientation was established in 1919 - 1938. In previous works of scientists investigating the choice of a profession the concept of prevocational education coincides with wider concept of vocational orientation. Jovaiša (1993) defines vocational orientation as "psychopedagogical guidance in choosing a profession, resolution, adaptation, acquiring a profession, employment and consolidation in professional work".

In $20^{\text {th }}$ century rapid progress of informational and communicational technologies, changes in the labour market, business, economy, essentially changed the requirements for employees predominant in the labour market and forced specialists to search for new methods of vocational education and training, to form new employees' skills. The investigations of the labour market have revealed that only vocational orientation is not enough for students with SEN to successfully adapt in the labour market. At the beginning of $21^{\text {st }}$ century the concepts of vocational orientation and prevocational training were changed by a wider concept of prevocational education. Prevocational education is defined by Laužackas (2005) as an activity of mainstream education striving to prepare the youth for wide perception of the world of work. The author distinguishes two main aspects of prevocational education - presentation of knowledge about a profession and development of the preconditions for subjective vocational life. Prevocational education of students with SEN 
comprises not only vocational counselling but also the development of students' general skills (social skills, basic skills, life skills), prevocational supervision and training, development of community-based educational experiences.

At the end of the $20^{\text {th }}$ century the movement of people with disability gains acceleration and strategic international documents regulating the integration of students with disability were issued. The UN Convention on the Rights of People with Disabilities adopted in 2006 indicates full and equal use of all human rights and main freedoms for people with disability as one of the aims. The UN Convention on the Rights of People with Disabilities assures nondiscrimination of people with disability in all the areas of life: equality against law, right to independent life, work and education, possibility to participate in political and cultural life are guaranteed.

In the $5^{\text {th }}$ decade of the last century in scientific literature the concepts of student career planning, career projection, preparedness for career, transition from school to adulthood appeared (Kochhar-Bryant, Greene, 2009), however, only now these concepts are theoretically actualized and today they are considered as measures ensuring the continuity of prevocational education of students with SEN.

The question of prevocational education of students with SEN is very relevant and little investigated. A unified theoretical model of prevocational education that could be practically implemented in schools has not been created yet. Therefore, problematic questions have been raised in the article: What are the preconditions and factors of prevocational education of students with SEN? What are the directions of the development of prevocational education of students with SEN?

The aim of this article - to reveal the directions of prevocational education of students with SEN, actual situation and opportunities.

\section{Methods of the research and sample characteristics}

To collect and process the data of the research qualitative and quantitative (calculations of means and polarity) approaches of social research have been combined. It means that refusing preconceived theoretical hypotheses it was oriented towards obtaining, description, structuralization (categorization) of practical experience of students with SEN, participants of the process of prevocational education. To collect the data of the research the Delphi method has been used.

In creating the methodology of the research of the Delphi group of the project it was referred to the regulations of the research of the Delphi group described in the works of Linstone, Turoff, (2002), Schniederjans, Hamaker, Schniederjans (2010), Buddenbaum, Novak (2001), Okoli, Pawlowski (2004) and other authors. 
The Delphi research was performed in several stages:

1. On the first stage, referring to the analysis of scientific and methodical literary sources the criteria were distinguished (operating description), that permit to correctly moderate constructive and productive discussions and reflections in the Delphi group and formulate the questions of the research based on scientific, empirical logic.

2. In order to collect the data of the research the questions were presented to the experts' group.

3. On the third stage, the results of the research of the Delphi group were analyzed in the qualitative approach using the method of grounded theory, the subcategories were distinguished and presented for experts' evaluation.

4. On the fourth stage the rankings of the experts' opinions were identified.

The method of the Delphi group is a debate under control that permits to avoid direct confrontation where an extreme opinion is expressed clearly, and the feedback is expressed coldly and without anger. The advantage of the method of the Delphi group is that the participants of the group can express their individual experience anonymously, which stimulates further and deeper discussions on the subject analyzed. Experts having practical and theoretical experience in the subject analyzed should be invited to the Delphi groups, they should be competent to respond to the questions prepared by the moderator of the research. In expressing the opinion feedback is accentuated and the conversation is directed not only to the identification of the problem but also to its solution presenting concrete recommendations, suggestions or ideas. The spectrum of the received opinions is systematized in the group itself using the methods of grounded theory. During the research the open type questions are raised, the participants of the group, the experts express their opinions reflecting their professional experience. The means of opinions are necessary for descriptive statistics in order to better understand the dissemination of the opinions of the experts' group during the whole process of the research.

All the statements obtained during the discussions are distinguished and grouped according to similar meanings. Then the nomination of the distinguished groups of statements takes place. Striving for objectivity of the contents of data and with the help of the experts the control of distinguishing notional units and contents of nomination is performed.

During the research the principles of anonymity were observed. During the research the concept of experts - the participants of the research - was used, which indicates the acknowledged status of the participants of the research.

The sample of the research of the Delphi group consisted of 13 experts (special pedagogues, psychologists, teachers of vocational training), having practical pedagogical working experience with students having special needs and working in mainstream schools, vocational schools, centres for special education and psychology. 
The research sample consisted of 2 men and 11 women having higher education. The essential principle of sampling was that only these people who directly work with students having SEN were invited to participate in the research of the Delphi group.

\section{Results of the research and their discussion Influence of traditions on the success of prevocational education of students with SEN}

The present chapter deals with economical and historical traditions of prevocational education of students with SEN in Lithuania and the areas to be improved. The statements expressed by the participants of the Delphi group were estimated and ranked according to importance. The numbers in the tables indicate the means of the scores of ranking scales (M). The estimation scales of situation and demand were five-ranked. In case of the estimation of situation: 1 total disagreement with the statement, 2 disagreement with the statement, 3 doubts about the expressed statement, 4 agreement with the statement, 5 total agreement with the statement, in case of the estimation of demand: 1 very bad, 2 bad, 3 I have doubts, 4 good, 5 very good. Polarity was also estimated, it identifies the gap between the estimations of situation and demand revealing the degree of the problematic character of the category, the gap between reality and aspirations, also the priority order of changes and activities.

The category "Students with mild SEN have the biggest possibilities in choosing profession" indicates the biggest gap between the estimation of situation and demand in comparison to other categories. Correspondingly this category is treated as the most problematic indicating that there is big lack in choosing vocational study programmes for students having severe and very severe SEN (see Table 1).

The second very important factor conditioning the success not only of prevocational education but also of vocational adaptation is the labour market. In the opinion of the participants of the Delphi group not only existing relation between the demand and supply of work but also employers' attitudes are important. According to the experts, society does not see economical profit in a student with SEN, often treats them as profit receivers, moreover, insufficiently developed employers' informational system does not establish preconditions for the formation of adequate employers' attitude towards the working skills of students with SEN. The attitude of the participants of the Delphi group is empirically proved by quantitative researches previously performed in Lithuania during which it was found out that employers who had never had practical experience with employees having special needs tend less to collaborate with educational institutions, to employ students with SEN or provide them with conditions for practical trainings. They do not trust in skills of students with 
SEN because they think that a person with special needs is not able to learn the whole process of work. On the other hand, the attitude of employers who had had experience with employees with disability towards the possibilities of employing people with SEN is more positive almost in all respects (Metsola, L.; Spichtinger, U.; Grazioli, P.; Baranauskienè, I.; Radzevičienè, L.; Valaikienè, A.; Kossewska, J.; Kijak, R.; Aspelund, S., 2012). The researches highlight the systemic approach towards the process of prevocational education of students with SEN indicating that in the process of education ensuring interinstitutional collaboration and involvement of social partners in the process of education is the most important. The integration of students with SEN in the labour market may be ensured by appropriately organized social policy, motivating employers with advantages and subsidies.

The third negative factor is insufficient prevocational training and counselling of students with SEN. The participants of the Delphi group accentuate insufficient acquaintance with vocational education among students with SEN, that is why in vocational schools students often have fears and do not trust in their abilities to acquire special (vocational) skills. Prevocational education in schools is not enough encouraged so far, the participants of the Delphi group indicate insufficient financing of these services from the state (lack of financing to ensure the continuity of projects, not allocating money for salaries), and also insufficient preparedness of teachers, lack of knowledge and experience to render vocational counselling and orientation.

Table 1

Influence of traditions on prevocational education of students with SEN

\begin{tabular}{|l|l|l|l|}
\hline \multicolumn{1}{|c|}{ Statements expressed in the group } & $\begin{array}{l}\text { Situation } \\
(\mathbf{M})\end{array}$ & $\begin{array}{l}\text { Demand } \\
\text { (M) }\end{array}$ & Polarity \\
\hline $\begin{array}{l}\text { Students with mild SEN have the biggest } \\
\text { possibilities in choosing professions. }\end{array}$ & 4,6 & 1,6 & 3 \\
\hline It is difficult to integrate in the labour market. & 4 & 1,6 & 2,8 \\
\hline $\begin{array}{l}\text { Employers informational system about students } \\
\text { with SEN is insufficiently developed. }\end{array}$ & 4 & 1,6 & 2,8 \\
\hline $\begin{array}{l}\text { Too little financing to ensure the continuity of } \\
\text { project activities. }\end{array}$ & 4,2 & 1,6 & 2,6 \\
\hline $\begin{array}{l}\text { The attitude exists that people with SEN are } \\
\text { dependents on the society, they can live only in } \\
\text { boarding-houses or receiving reliefs. }\end{array}$ & 4 & 1,4 & 2,6 \\
\hline Insensibility of policy makers to social problems. & 4 & 1,4 & 2,6 \\
\hline $\begin{array}{l}\text { Insufficient relation between a student and social } \\
\text { partners. }\end{array}$ & 4 & 1,8 & 2,2 \\
\hline Insufficient encouragement of social enterprises. & 4 & 2 & 2,6 \\
\hline $\begin{array}{l}\text { Society does not see economical profit in a } \\
\text { student with SEN. }\end{array}$ & 3,8 & 1,2 & 2,6 \\
\hline $\begin{array}{l}\text { Insufficient understanding of society of the need } \\
\text { for prevocational education. }\end{array}$ & 3,8 & 1,6 & 2,2 \\
\hline
\end{tabular}




\begin{tabular}{|l|l|l|l|}
\hline $\begin{array}{l}\text { Employers' fear to employ a person with } \\
\text { disability. }\end{array}$ & 3,6 & 1,6 & 2 \\
\hline $\begin{array}{l}\text { Lack of communication between parents and } \\
\text { children. }\end{array}$ & 3,6 & 2,2 & 1,4 \\
\hline $\begin{array}{l}\text { In mainstream schools students are too little } \\
\text { acquainted with vocational education, that is why } \\
\text { children are afraid of vocational education lessons } \\
\text { in vocational schools. }\end{array}$ & 3,6 & 1,8 & 1,8 \\
\hline $\begin{array}{l}\text { Too little teachers' interest in encouraging a child } \\
\text { to choose a profession. }\end{array}$ & 3,6 & 2,2 & 1,4 \\
\hline $\begin{array}{l}\text { Insufficient teachers' ability to provide vocational } \\
\text { counselling and orienting. }\end{array}$ & 3,6 & 2,2 & 1,4 \\
\hline
\end{tabular}

In case of evaluation of situation the statements of the participants of the Delphi group were evaluated as follows: 1 very bad, 2 bad, 3 I have doubts, 4 good, 5 very good and, in case of evaluation of demand: 1 not important at all, 2 not important, 3 I have doubts, 4 important, 5 very important.

Table 2

Traditions that may help with prevocational education of students with SEN

\begin{tabular}{|l|l|l|l|}
\hline \multicolumn{1}{|c|}{ Statements expressed in the group } & $\begin{array}{l}\text { Situation } \\
\text { (M) }\end{array}$ & $\begin{array}{l}\text { Demand } \\
\text { (M) }\end{array}$ & Polarity \\
\hline $\begin{array}{l}\text { Teacher's professional preparedness to work } \\
\text { with a student having SEN. }\end{array}$ & 2,4 & 5 & 2,6 \\
\hline $\begin{array}{l}\text { Every student with SEN is accepted as a free } \\
\text { personality and the conditions to realize his/her } \\
\text { abilities according to possibilities are created. }\end{array}$ & 2,4 & 4,8 & 2,4 \\
\hline $\begin{array}{l}\text { Special attention is paid to working (vocational) } \\
\text { activity participating in real activity. }\end{array}$ & 2 & 4,8 & 2,8 \\
\hline $\begin{array}{l}\text { Encouragement of economical usefulness and } \\
\text { occupation, students with SEN acquire } \\
\text { respective qualification in order to adapt to } \\
\text { social environment and labour market. }\end{array}$ & 2 & 4,8 & 2,8 \\
\hline $\begin{array}{l}\text { In schools there are vocational information } \\
\text { points, services of vocational informing and } \\
\text { counselling on the issues of vocational } \\
\text { purposefulness and suitability are rendered. }\end{array}$ & 3,4 & 4,8 & 1,4 \\
\hline Teacher's empathy. & 3 & 4,6 & 1,6 \\
\hline $\begin{array}{l}\text { Student is supervised. After graduation there is } \\
\text { coordination of future vocational career. }\end{array}$ & 2 & 4,6 & 2,6 \\
\hline $\begin{array}{l}\text { There are "mediators" between educational } \\
\text { institutions and social partners. }\end{array}$ & 1,8 & 4,6 & 2,8 \\
\hline $\begin{array}{l}\text { Establishing enterprises that could give } \\
\text { possibility for a student with SEN to work } \\
\text { practically. }\end{array}$ & 2 & 4,4 & 2,4 \\
\hline $\begin{array}{l}\text { Activeness of a person with disability in search } \\
\text { of a job. }\end{array}$ & 3 & 4,4 & 1,4 \\
\hline
\end{tabular}


Establishing social accommodation with service in order to form social skills and retain independence.

\begin{tabular}{|l|l|l|} 
& & \\
2,4 & 4 & 1,6 \\
\hline
\end{tabular}

The participants of the Delphi group indicating the directions of prevocational education to be improved emphasize teacher's professional preparedness to work with students having SEN, however, when a student learns in inclusive environment teachers not always are practically prepared to render qualified pedagogical assistance because of lack of time and knowledge. Kluth, Biklen English-Sand, and Smukler (2007) write that quite often even inclusive education is faced with a range of obstacles, including educational segregation, inappropriate curricula, lack of appropriate support and servines, and social rejections. The category "Teacher's professional preparedness to work with a student having SEN", is strengthened by "Every student with SEN is accepted as a free personality and the conditions to realize his/her abilities according to possibilities are created" (see Table 2). Inclusive education should be understood not only as educating students having different needs together, but also creating suitable conditions providing schools with sufficient number of methodical aids prepared with regard to students' different needs, compensatory technique, also establishing preconditions to render sufficient pedagogical supervision and assistance to students.

Encouragement of vocational activity and occupation of students with SEN is necessary in order to gain practical experience and real life skills, expand social relations and change the attitude of society towards an employee with disability. However, it is not sufficient for a student to successfully integrate in the labour market. The participants of the Delphi group point out the necessity of the coordination of further vocational career, raising a task for social institutions to register all students with SEN and render them psychological and pedagogical assistance in transition from youth to adulthood and helping to suitably take up the new roles and duties of employee, citizen, community member, father or mother. The majority of students with SEN are from families getting social assistance, therefore, the experts suggest establishing social accommodation with service in order to form social skills and retain independence of students with SEN.

\section{Importance of creating the interaction child-family-school- community}

Wagner and Davis (2006) in analyzing the results of longitude research by the other authors distinguish effective support from school creating positive relations as a basis helping students to get involved in school life as one of five principles of prevocational education conditioning positive experience of mainstream school for students with special educational needs and successful 
transition to early adulthood. Factors determining positive relations: smaller school or class size, formation of small educational communities, implementation of mentorship programmes in schools, rendering assistance to students with SEN (development of social skills helping to reduce the impact of a disorder on the formation of relations).

Table 3

\section{Interaction child - school}

\begin{tabular}{|c|c|c|c|}
\hline Statements expressed in the group & $\begin{array}{l}\text { Situation } \\
\text { (M) }\end{array}$ & $\begin{array}{l}\text { Demand } \\
\text { (M) }\end{array}$ & Polarity \\
\hline $\begin{array}{l}\text { In schools there should be specially adjusted } \\
\text { equipment, visual aids, methodical material. }\end{array}$ & 3 & 5 & 2 \\
\hline Teacher's education, in-service training. & 2,6 & 4,8 & 2,2 \\
\hline $\begin{array}{l}\text { Development of competences necessary for } \\
\text { person's future professional activity. }\end{array}$ & 2,6 & 4,8 & 2,2 \\
\hline $\begin{array}{l}\text { Team assistance from all the specialists of } \\
\text { educational assistance. }\end{array}$ & 3 & 4,6 & 1,6 \\
\hline Strengthening of self-confidence. & 3 & 4,6 & 1,6 \\
\hline Formation of social and communication skills. & 3 & 4,6 & 1,6 \\
\hline Correction of behaviour. & 2,8 & 4,6 & 1,8 \\
\hline $\begin{array}{l}\text { Formation of positive peers' attitude towards } \\
\text { students with SEN. }\end{array}$ & 3 & 4,6 & 1,6 \\
\hline $\begin{array}{l}\text { Constant communication and collaboration with } \\
\text { peers. }\end{array}$ & 2,6 & 4,6 & 2 \\
\hline Strengthening of learning motivation. & 2,4 & 4,6 & 2,2 \\
\hline $\begin{array}{l}\text { To develop cognitive abilities, to teach how to } \\
\text { use sources of information. }\end{array}$ & 3,2 & 4,6 & 1,4 \\
\hline $\begin{array}{l}\text { To improve cognitive functions necessary for } \\
\text { future profession. }\end{array}$ & 2,8 & 4,6 & 1,8 \\
\hline $\begin{array}{l}\text { To help a student to evaluate his/her } \\
\text { possibilities. }\end{array}$ & 3 & 4,6 & 1,6 \\
\hline $\begin{array}{l}\text { Class size should be chosen with regard to what } \\
\text { special educational needs a student has. }\end{array}$ & 2,4 & 4,8 & 2,4 \\
\hline $\begin{array}{l}\text { Classes should be of such size as to permit a } \\
\text { teacher to give enough attention to all students. }\end{array}$ & 2,2 & 4,8 & 2,6 \\
\hline $\begin{array}{l}\text { In classes there should be no more than } 5 \\
\text { students with intellectual, behavioural and } \\
\text { complex needs. }\end{array}$ & 2 & 4,5 & 2,5 \\
\hline Involving in joint activities with other students. & 2,8 & 4,4 & 1,6 \\
\hline Provision with special educational aids. & 3,4 & 4,4 & 1 \\
\hline $\begin{array}{l}\text { To perform various prevention programmes of } \\
\text { children's occupation, to maintain relations with } \\
\text { various institutions in the community. }\end{array}$ & 2,8 & 4,4 & 1,6 \\
\hline Inclusive environment is important. & 2,8 & 4,4 & 1,6 \\
\hline $\begin{array}{l}\text { To provide necessary assistance to a student in } \\
\text { analyzing his/her environment, to help to find } \\
\text { suitable ways of solving problems. }\end{array}$ & 3,2 & 4,2 & 1 \\
\hline
\end{tabular}




\begin{tabular}{|l|r|r|r|}
\hline To help a student to know himself/herself. & 2,6 & 4,2 & 1,6 \\
\hline $\begin{array}{l}\text { Psychologist may help a class tutor to learn } \\
\text { about the interests, inclinations, intentions of the } \\
\text { students of his/her class. }\end{array}$ & 3 & 4,2 & 1,2 \\
\hline $\begin{array}{l}\text { To strengthen children's psychological } \\
\text { resilience, to teach how to overcome difficulties. }\end{array}$ & 2,6 & 4,2 & 1,6 \\
\hline $\begin{array}{l}\text { Teacher assistant should help to perform } \\
\text { activities related to education, to appropriately } \\
\text { use technical measures of assistance. }\end{array}$ & & 3,2 & 4,2 \\
\hline $\begin{array}{l}\text { Teacher assistant should help a student to safely } \\
\text { orientate at school and out of school. }\end{array}$ & 3,4 & 4,2 & 0,8 \\
\hline $\begin{array}{l}\text { To meet internal and external needs of a student } \\
\text { with SEN. }\end{array}$ & 2,8 & 4 & 1,2 \\
\hline $\begin{array}{l}\text { Rooms oriented towards concrete specialities } \\
\text { suitable for students are established. }\end{array}$ & 1,8 & 4 & 2,2 \\
\hline
\end{tabular}

In order to achieve one of the objectives of prevocational education - successful vocational adaptation of students with SEN - creating and maintaining of positive students' experience at school is important. In order for a child to achieve optimal learning results firstly all his/her internal and external needs should be satisfied. In this aspect the participants of the Delphi group emphasize team work of all the specialists of education (see Table 3).

Formation of social skills (adequate self-assessment, appropriate behaviour, etc.), involvement of students with SEN in joint activities together with all the participants of the process of education is necessary in order to ensure positive relations with peers and teachers. Students at school should be taught communication skills, how to manage emotions, solve conflicts, know the main requirements of etiquette, have the skills of hygiene.

Table 4

Importance of involving a student and his/her family in the process of prevocational education

\begin{tabular}{|l|l|l|l|}
\hline \multicolumn{1}{|c|}{ Statements expressed in the group } & $\begin{array}{l}\text { Situation } \\
\text { (M) }\end{array}$ & $\begin{array}{l}\text { Demand } \\
\text { (M) }\end{array}$ & Polarity \\
\hline $\begin{array}{l}\text { Parents should observe child's interests, abilities, } \\
\text { hobbies. }\end{array}$ & 3,6 & 4,8 & 1,2 \\
\hline $\begin{array}{l}\text { Parents should be involved in collaboration on } \\
\text { interinstitutional level and on the level of school } \\
\text { community. }\end{array}$ & 2,6 & 4,8 & 2,2 \\
\hline Formation on parents' positive attitudes. & 2,8 & 4,6 & 1,8 \\
\hline $\begin{array}{l}\text { To strive that parents adequately evaluate their } \\
\text { children's possibilities, encourage them and help } \\
\text { them improve working skills. }\end{array}$ & 2,6 & 4,6 & 2 \\
\hline $\begin{array}{l}\text { During parents' meetings to organize meetings with } \\
\text { specialists in educational assistance, vocational } \\
\text { counsellor, coordinator of prevocational education. }\end{array}$ & 2,8 & 4,4 & 1,6 \\
\hline
\end{tabular}




\begin{tabular}{|l|l|l|l|}
\hline $\begin{array}{l}\text { To provide parents with information about the news } \\
\text { in the labour market, changes, educational }\end{array}$ & & & \\
$\begin{array}{l}\text { institutions where specialities can be acquired, } \\
\text { requirements for particular profession, actual } \\
\text { possibilities of their children. }\end{array}$ & 2,6 & 4,4 & 1,8 \\
\hline Giving parents purposeful directions. & 2,4 & 4,4 & 2 \\
\hline $\begin{array}{l}\text { To constantly provide parents with information about } \\
\text { students' achievements. }\end{array}$ & 3,8 & 4,4 & 0,6 \\
\hline $\begin{array}{l}\text { Preparation of individual transition plan from school } \\
\text { to vocational activity. }\end{array}$ & 2 & 4,4 & 2,4 \\
\hline $\begin{array}{l}\text { Parents' collaboration with pedagogues in identifying } \\
\text { student's abilities. }\end{array}$ & 2,8 & 4,2 & 1,4 \\
\hline $\begin{array}{l}\text { Joint activities, attractions, trips, meetings, festivals } \\
\text { together with parents are planned. }\end{array}$ & 3,2 & 4 & 0,8 \\
\hline $\begin{array}{l}\text { Persuasion of parents in the success of collaborative } \\
\text { activity. }\end{array}$ & 2,6 & 4 & 1,4 \\
\hline Create joint projects with parents. & 2 & 3,8 & 1,8 \\
\hline $\begin{array}{l}\text { Parents should be provided with psychological } \\
\text { assistance. }\end{array}$ & 2,8 & 3,6 & 0,8 \\
\hline
\end{tabular}

Parents raising children with SEN often overestimate or underestimate their abilities (Metsola, Spichtinger, Grazioli, Baranauskienè, Radzevičienè, Valaikiené, Kossewska, Kijak, Aspelund, 2012), therefore, the participants of the Delphi group emphasize the need for social, pedagogical and psychological work with parents (see Table 4). Parents should also help their children to choose a profession observing their needs, interests and inclinations. However, they should be purposefully trained by specialists how they should perform this observation and construct a conversation with a child.

The second not less important objective is to participate together with a child in preparing a particular individual transition plan from mainstream school to vocational school (or vocational activity). Parents, as well as children, not always know the possibilities of choosing a profession, getting social allowance, therefore, in creating a vocational career plan it would be possible to consider all the solutions together with specialists, to solve problems that before the counselling may seem as the main insurmountable obstacles in choosing a profession. Clear knowing what one wants gives a direction to efforts and makes them more effective. Realized wishes are a strong motivating power.

Career planning is a life long process because the external world is constantly changing (new requirements for the workplace, disappearance of professions, reorganizations of enterprises, etc). People constantly gain new experience, knowledge, change their attitude. Self-cognition, analysis of vocational possibilities, setting new aims of life, career and education should be a constant process, therefore, one of the aims of counselling should be not only to help to create a career plan for today, but teach students and their parents to create a career plan themselves and take personal responsibility for it. 
Importance of the creation of the interaction child - community

\begin{tabular}{|l|l|l|l|}
\hline \multicolumn{1}{|c|}{ Statements expressed in the group } & $\begin{array}{l}\text { Situation } \\
(\mathbf{M})\end{array}$ & $\begin{array}{l}\text { Demand } \\
\text { (M) }\end{array}$ & Polarity \\
\hline Open door days in enterprises. & 2,4 & 4,8 & 2,4 \\
\hline $\begin{array}{l}\text { To organize exhibitions of children's works, } \\
\text { other events in the city. }\end{array}$ & 3,4 & 4,6 & 1,2 \\
\hline $\begin{array}{l}\text { Students with SEN should experience success } \\
\text { more often. }\end{array}$ & 2,6 & 4,6 & 2 \\
\hline To invite employers to joint events. & 2,4 & 4,6 & 2,2 \\
\hline $\begin{array}{l}\text { To encourage constant participation in social } \\
\text { events of the city. }\end{array}$ & 2,8 & 4,2 & 1,4 \\
\hline
\end{tabular}

The practice of the creation of the interaction child - community in Lithuania is still in the stage of formation. It is agreed with the opinion that students with SEN should be encouraged to participate in the life of society, however, so far the possibilities to participate in the events of the community presenting works in exhibitions, participating in contests, to go to open door days organized in enterprises are offered (see Table 5).

Table 6

Aims of prevocational education of students with SEN

\begin{tabular}{|l|l|l|l|}
\hline \multicolumn{1}{|c|}{ Statements expressed in the group } & $\begin{array}{l}\text { Situatio } \\
\text { n (M) }\end{array}$ & $\begin{array}{l}\text { Demand } \\
\text { (M) }\end{array}$ & Polarity \\
\hline $\begin{array}{l}\text { Development of practical and social skills in } \\
\text { students with SEN. }\end{array}$ & 3 & 4,8 & 1,8 \\
\hline Development of skills of independent life. & 2,6 & 4,8 & 2,2 \\
\hline $\begin{array}{l}\text { To help each child to find and gain a profession } \\
\text { corresponding to his/her wishes and possibilities. }\end{array}$ & 2,4 & 4,8 & 2,4 \\
\hline $\begin{array}{l}\text { To help a student with SEN to understand the } \\
\text { reality of the possibilities of his/her choice. }\end{array}$ & 2,6 & 4,8 & 2,2 \\
\hline Practical probation of professions. & 2,2 & 4,8 & 2,6 \\
\hline $\begin{array}{l}\text { Student with SEN should feel as a person of full } \\
\text { value and needed for society. }\end{array}$ & 2,4 & 4,8 & 2,4 \\
\hline $\begin{array}{l}\text { To stimulate a wish for self-education, constant } \\
\text { perfection. }\end{array}$ & 2,8 & 4,8 & 2 \\
\hline $\begin{array}{l}\text { Development of sense of responsibility, duty, } \\
\text { honesty. }\end{array}$ & 3,2 & 4,6 & 1,4 \\
\hline Development of diligence. & 3 & 4,6 & 1,6 \\
\hline Self-cognition of a student with SEN. & 2,8 & 4,6 & 1,8 \\
\hline Gaining knowledge about professions. & 3,2 & 4,6 & 1,4 \\
\hline $\begin{array}{l}\text { To help a student with SEN to perceive personal } \\
\text { and social responsibility. }\end{array}$ & 2,6 & 4,6 & 2 \\
\hline To teach how to make a decision in life. & 2 & 4,6 & 2,6 \\
\hline $\begin{array}{l}\text { Close relations between school, family and } \\
\text { vocational counselling services. }\end{array}$ & 2,4 & 4,6 & 2,2 \\
\hline
\end{tabular}


The participants of the Delphi group emphasize the development of social skills and independent life skills as one of the main aims of prevocational education (see Table 6). Wishes not corresponding to possibilities or reality may remain just dreams, therefore, finding a profession corresponding to student's wishes and possibilities is emphasized.

Development of working skills comprises the development of responsibility, sense of duty, honesty, diligence, ability to responsibly make decisions.

The world is constantly changing: the amount of information is becoming larger, the technologies are improving and every stop that is too long may mean lagging behind. Disposition to learning facilitates the adaptation to changes and is one of the conditions of the competition in the labour market. Interests and being aware of them are one of the essential factors in choosing vocational activity. The researches prove that interests have stronger relation to choosing a profession than abilities. When there is lack of interest - the possibilities to form abilities, competences and skills are very small, even when having ideal preconditions for abilities and talents (Armalienè, Kriščiūnaite). Therefore, the motivation of life long learning in students with SEN should be constructed on the basis of there interests finding activities that are successful for them and bring them satisfaction.

\section{Conclusions}

1. The results of the research of the Delphi group have permitted to reveal the factors of prevocational education of students with SEN and the directions to be improved: in the country too few possibilities in choosing a profession are given to students with severe and very severe SEN, negative employers' attitudes, insufficient encouragement of prevocational education reduce the possibilities of vocational realization of students with SEN. More attention should be paid to training and encouragement of teachers to implement the aims of prevocational education, the continuity of prevocational education of students with SEN should be practically performed, the aim of which is to ensure successful transition from school to adulthood.

2. Creation of positive relation between a student with SEN and school should be performed meeting internal and external child's needs, forming social skills. Assistance to a student should be complex and rendered in systematic collaboration between the specialists in different areas.

3. In order to optimize prevocational education parents need social and psychological support as well in order to better know child's needs, appropriately discuss the possibilities of vocational career. In creating an individual vocational career plan specialists should also involve parents in order to consider all the solutions, to solve problems that before the 
counselling may seem as the main insurmountable obstacles in choosing a profession.

4. The participants of the Delphi group accentuate the development of social skills and independent life skills in students with SEN and vocational counselling as one of the main aims of prevocational education. In students' choosing a profession the process of the coordination of interests and abilities could take place during practical work classes.

\section{Summary}

Rapid progress of informational and communicational technologies, changes in the labour market, business, economy, essentially changed the requirements for employees predominant in the labour market and forced specialists to search for new methods of vocational education and training, to form new employees' skills. Striving for successful transition of students with SEN from school to adulthood prevocational education becomes especially relevant.

In 2012 in Lithuania the research of the Delphi group was performed where 13 experts having direct pedagogical experience in working with students having SEN participated.

The aim of this article - to reveal the directions of prevocational education of students with SEN, actual situation and opportunities.

Practical experience of the participants of the research has permitted not only to reveal structural and in-depth factors of prevocational education of students with SEN but also foresee strategic directions of changes.

The participants of the Delphi research accentuate the necessity of encouragement and suitable preparedness of teachers to implement prevocational education, development of social skills and independent life skills in students with SEN, development of working skills. They indicate specialists' support in the period after graduation as one of the main condition of the success of prevocational education that helps a student with SEN in successful transition from school to adulthood.

\section{Bibliography}

1. Armalienė, D.; Kriščiūnaitè, R. Siek, planuok, veik. Kaip teisingai pasirinkti karjeros kelią. Švietimo mainų paramos fondas.

2. Buddenbaum J., M.; Novak, K., B. (2001). Applied Communication Research. Usa: Iowa State University Press.

3. Kluth, P., Biklen, D. English-Sand, P., Smukler, D. (2007). Going Away to School. Stories of Families who Move to Seek Inclusive Educational Experience for Their Children with Disabilities. Journal of Disability PolicyStudies, 18 (1), 43-56.

4. Kochhar-Bryant, C.; Greene, G. (2009). Pathways to Successful Transition for Youth with Disabilities. 2nd Edition. ISBN 13: 978-0-13-205086-9.

5. Laužackas, R. (2005). Profesinio rengimo metodologija. Monografija. Kaunas.

6. Linstone, H., A.; Turoff, M. (2002). The Delphi Method Techniques and Applications. USA. 
7. Metsola, L.; Spichtinger, U.; Grazioli, P.; Baranauskienè, I.; Radzevičienè, L.; Valaikienè, A.; Kossewska, J.; Kijak, R.; Aspelund, S. (2012). Vocational Counselling for Children \& Youth with Special Educational Needs. ISBN kodas: 978-83-7271-740-5. Lenkija: Wydawnictwo Naukowe Uniwersytetu Pedagogicznego Krakow. P. 9-29, $127-$ 205, 363-379.

8. Okoli, Ch.; Pawlowski, S. D. (2004). The Delphi method as a research tool: an example, design considerations and applications. Information \& Management. 42. P. 15-29. Prieiga internete:

From:http://chitu.okoli.org/images/stories/bios/pro/research/methods/OkoliPawlowski200 4.pdf.

9. Schniederjans, M., J.; Hamaker, J., L.; Schniederjans, A., M. (2010). Informatikon Technology Investment. Decision-Making Methodology. 2 nd Edition. Singapore: World Scientific Publishing Co.Pte.Ltd. ISBN-13 978-981-4282-56-7.

10. Jovaiša, L. (1999). Profesinio konsultavimo psichologija. Vilnius.

11. Jurevičiūtè, K. Ikiprofesinio ugdymo sampratu raida Lietuvoje. Tiltai. 2007, 4. ISSN 1392-3137.

12. Wagner, M.; Davis, M. (2006). How are we preparing Students With Emotional Disturbances for the Transition to Young Adulthood? Journal of Emotional and behavioral disorders. Vol. 14 No. 2. P. $86-98$.

\begin{tabular}{|c|c|}
\hline $\begin{array}{r}\text { Ingrida } \\
\text { Baranauskienè }\end{array}$ & $\begin{array}{l}\text { Šiauliai University, Faculty of Social } \\
\text { Welfare and Disability Studies } \\
\text { P. Višinskio str. 25, LT-76351 Šiauliai, } \\
\text { Lithuania } \\
\text { E-mail: i.baranauskiene@cr.su.lt } \\
\text { Phone: +37041595747 }\end{array}$ \\
\hline Aistė Valaikienė & 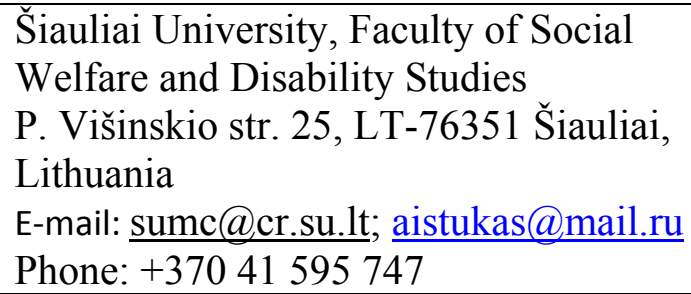 \\
\hline
\end{tabular}

